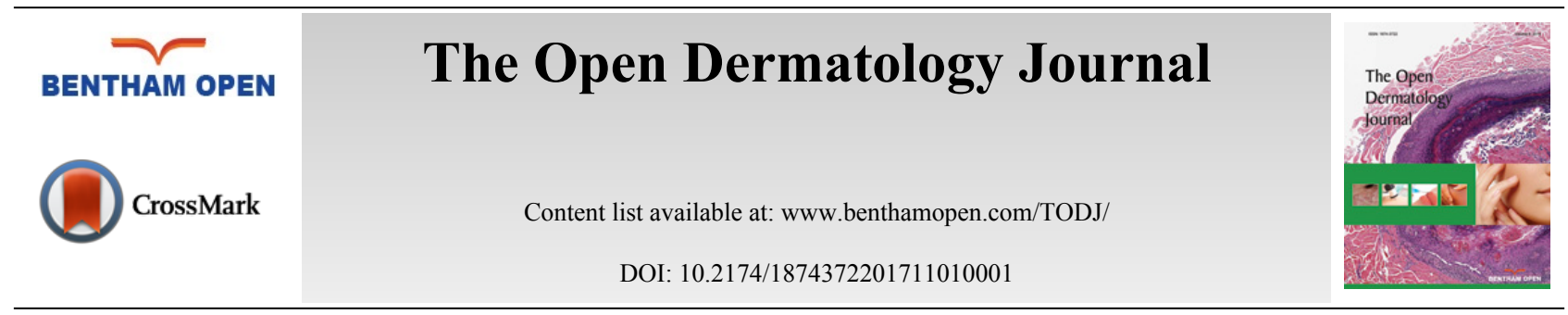

REVIEW ARTICLE

\title{
Localized Scleroderma: Predisposing and Triggering Factors
}

\author{
Irina Khamaganova* \\ Pirogov Russian National Medical University, 2 Krestovsky 8, 31, Moscow, Russia
}

Received: October 11, 2016

Revised: November 30, 2016

Accepted: December 02, 2016

\begin{abstract}
The etiology of localized scleroderma remains unclear. The objective of this article is to review different theories of etiology, specifically provocative and predisposing factors for the development of localized scleroderma. The mini-review presents the factors, which may influence the occurrence of localized scleroderma. The genetic predisposition for the development of scleroderma is a relevant characteristic of the disease. Different traumatic factors, viral \& bacterial infections, chemical substances, pharmaceutical agents may trigger localized scleroderma. Neoplasia is regarded as a distinct triggering impulse for scleroderma.
\end{abstract}

Keywords: Chemical agents, Etiology, Genetics, Infections, Localized scleroderma, Malignancy.

\section{INTRODUCTION}

Scleroderma is considered a tripartite disease associated with autoimmune, fibroblast and endothelial disorders. The nomenclature of scleroderma has changed dramatically in recent years, with morphoea (localized scleroderma), limited cutaneous systemic sclerosis, diffuse cutaneous systemic sclerosis, and systemic sclerosis sine scleroderma encompassing the currently accepted disease subtypes. Major advances have been made in the molecular studies of localized scleroderma. However, the etiology of the disease remains not yet entirely understood [1]. Many factors are being discussed as provocative for the occurrence of scleroderma: genetic factors, trauma, viral \& bacterial infections, toxic substances or pharmaceutical agents $[2,3]$.

The objective of this article is to summarize different theories of etiology, provocative and predisposing factors for the development of localized scleroderma, using a review of literature.

\section{MATERIALS AND METHODS}

The main source of information was Medline Pubmed including original articles, reviews, cases and clinical guidelines. The keywords "localized scleroderma" and "etiology" were used. 360 publications from 2010 to September 2016 were analyzed. We selected 95 publications that presented the provocative $\&$ predisposing factors for localized scleroderma development.

\section{INCLUSION AND EXCLUSION CRITERIA}

The review articles, retrospective cohort studies, case series and case reports were included. The articles published before 2010 were excluded.

\section{RESULTS}

The results are summarized in Table $\mathbf{1}$.

\footnotetext{
* Address correspondence to this author at the Pirogov Russian National Medical University, 2 Krestovsky 8, 31, Moscow, Russia; Tel: +7 985998 44 81; Fax: 7495 770-09-51; E-mails: superbirina@yandex.ru, clinderm11@gmail.com
} 


\section{The Genetic Predisposition}

On the one hand, the genetic predisposition to localized scleroderma is examined. Family cases of localized scleroderma are known. For example, a case of localized scleroderma affecting both a father and a son was presented by Pham CM \& Browning JC, (2010) [4].

In the genesis of scleroderma on the other hand, $\mathrm{X}$ chromosome monosomy is considered important by Karaca NE \& colleagues, (2011) [5]. A case of female monozygotic twins who presented co-existence of localized scleroderma and lichen sclerosis was described. Co-existence of these diseases in monozygotic twins indicated the possible genetic contribution to the genesis of localized scleroderma and lichen sclerosis [6]. The influence of HLA haplotypes is crucial for various molecular mechanisms, leading to fibrosis in both the skin and the underlying connective tissue [7]. The specific HLA class I and class II alleles are associated with localized scleroderma and are also likely to be associated with generalized and linear subtypes of localized scleroderma. Jacobe H \& colleagues, (2014) found the strongest associations with DRB1*04:04 and HLA-B*37 among the class 1 alleles [8].

Table 1. Localized scleroderma: predisposing \& triggering factors.

\begin{tabular}{|c|c|c|}
\hline Triggers & Factors & Authors \\
\hline \multirow[t]{3}{*}{$\begin{array}{l}\text { genetic } \\
\text { predisposition: }\end{array}$} & family cases & $\begin{array}{l}\text { Pham CM, Browning JC.(2010) [4],Lis- Święty A, Mierzwińska K, Wodok- Wieczorek K, } \\
\text { Widuchowska M, Brzezińska- Wcisło L.(2014) [6] }\end{array}$ \\
\hline & X-chromosome monosomy & $\begin{array}{l}\text { Karaca NE, Aksu G, Karaca E, Tuzun F, Gunes AT, Ozkinay F, } \\
\text { Kutukculer N.(2011) [5] }\end{array}$ \\
\hline & the influence of HLA haplotypes & $\begin{array}{l}\text { Canady J., Karrer S., Fleck M., Bosserhoff A.K.(2013) [7], } \\
\text { Jacobe H, Ahn C, Arnett FC, } \\
\text { Reveille JD. (2014) [8] }\end{array}$ \\
\hline \multirow[t]{3}{*}{$\begin{array}{l}\text { endocrine } \\
\text { changes: }\end{array}$} & pregnancy & $\begin{array}{l}\text { Noda S, Asano Y, Ashida R, Tomita M, Kawashima T, Sato S.(2011) [9], Benchat L, } \\
\text { Mernissi F.Z.(2013) [10],Wong B, Pilouras P, Mortimore R, Zonta M., Tucker S.(2015) } \\
\text { [11] }\end{array}$ \\
\hline & thyroid dysfunctions & $\begin{array}{l}\text { Bonilla- Abadia F., Muñoz- Buitron E, Ochoa CD, Carrascal E., Cañas CA (2012) } \\
\text { [13],Hassan I., Arif T, Anwar P.(2014) [12] }\end{array}$ \\
\hline & diabetes mellitus & Firoz EF, Kamino H, Lehman TJ, Orlow SJ(2010) [22] \\
\hline \multirow[t]{4}{*}{ trauma: } & physical injuries & $\begin{array}{l}\text { Fett N, Werth VP. (2011) [1], Browning JC. (2013) [29], Arif T.et al.(2015) [23], Arif T., } \\
\text { Majid I.(2015) [24],, Careta MF, Romiti R(2015) [28],Touloei K, Wiener A, Glick BP. } \\
\text { (2015) [31],Wolf R, Wolf D, Ruocco V, Ruocco E. (2015) [26] }\end{array}$ \\
\hline & mechanical compression by clothes & Grabell D, Hsieh C, Andrew R, Martires K, Kim A, Vasquez R, Jacobe H. (2014) [25] \\
\hline & wearing slimbelt & Arif T.et al.(2015) [27] \\
\hline & injection & Ueda T, Niiyama S, Amoh Y, Katsuoka K. (2010) [33] \\
\hline \multirow[t]{4}{*}{ infections: } & cytomegalovirus & $\begin{array}{l}\text { Goulabchand R, Khellaf L, Forestier A, Costes V, Foulongne V, le Quellec A, Guilpain P } \\
\text { [34]. }\end{array}$ \\
\hline & varicella & Patel H, Thakkar C, Patel K.(2010) [35], Qu T, Fang K. (2014) [36] \\
\hline & HIV & Mosquera JA, Ojea R, Navarro C. (2010) [37] \\
\hline & borrelia infection & $\begin{array}{l}\text { Espinoza-León F, Arocha F, Hassanhi M, Arévalo J.(2010) [38], Zollinger T, Mertz KD, } \\
\text { Schmid M, Schmitt A, Pfaltz M, Kempf W. (2010) [47], Santos M, Ribeiro- Rodrigues R, } \\
\text { Talhari C, Ferreira LC, Zelger B, Talhari S. (2011) [39],Moniuszko A, Gińdzieńska- } \\
\text { Sieśkiewicz E, Pancewicz SA, Czupryna P, Zajkowska J, Sierakowski S. (2012) } \\
\text { [40],Miglino B, Viana M, Zavattaro E, Bonin S, Valente G, Colombo E. (2012) [41],Miller } \\
\text { K, Lehrhoff S, Fischer M, Meehan S, Latkowski JA(2012) [42], Inci R, Inci MF, Ozkan F, } \\
\text { Oztürk P. (2012) [43], di Meo N, Stinco G, Nan K, Pinzani C, Trevisan G. (2015) } \\
\text { [44],Aberer E, Wutte N,(2016) [45],Trevisan G., Trevisini S., di Meo N., (2016) [46], } \\
\text { Gutiérrez- Gómez C, Godínez- Hana AL, García- Hernández M, Suárez-Roa M deL, } \\
\text { Toussaint-Caire S, Vega- Memije E, Gutiérrez- Mendoza D, Pérez-Dosal M, Medina-Dela } \\
\text { Garza CE(2014) [48],Verberkt RM, Janssen M, Wesseling J. (2014) [49] }\end{array}$ \\
\hline \multirow[t]{4}{*}{ vaccinations: } & hepatitis B & $\begin{array}{l}\text { Benmously Mlika R, Kenani N, Badri T, Hammami H, Hichri J, Haouet S, Mokhtar I, } \\
\text { Fenniche S. (2010) [50] }\end{array}$ \\
\hline & diphtheria/tetanus/pertussis & Khaled A, Kharfi M, Zaouek A, Rameh S, Zermani R, Fazaa B, Kamoun MR. (2012) [51] \\
\hline & measles/mumps/rubella & Weibel L. (2012) [52] \\
\hline & pneumococcal vaccination & Viladomiu Edel A, Valls AT, Zabaleta BA, Moreno AJ, Pérez NO(2014) [53] \\
\hline \multirow[t]{3}{*}{ chemical agents } & pesticides & Sozeri B, Gulez N, Aksu G, Kutukculer N, Akalın T, Kandiloglu G. (2012) [54] \\
\hline & silicone & Kivity S, Katz M, Langevitz P, Eshed I, Olchovski D, Barzilai A. (2012) [55] \\
\hline & adjuvants & Frances L, Leiva- Salinas M, Angelica MB, Marin I, Silvestre JF. (2014) [56] \\
\hline
\end{tabular}




\begin{tabular}{|c|c|c|}
\hline Triggers & Factors & Authors \\
\hline \multirow{9}{*}{$\begin{array}{l}\text { pharmaceutical } \\
\text { agents }\end{array}$} & valproate & Aslan A.,Kotoroglu G.,Sözeri B.,Kurugöl Z. (2014) [59] \\
\hline & TNF-alpha inhibitors & $\begin{array}{l}\text { Mattozzi C, Richetta AG, Cantisani C, Giancristoforo S, D’Epiro S, Gonzalez Serva A, } \\
\text { Viola F, Cucchiara S, Calvieri S. (2010) [61] }\end{array}$ \\
\hline & & $\begin{array}{l}\text { Ramírez J, Hernández MV, Galve J, Cañete JD, Sanmartí R(2012) [62],Stewart FA, } \\
\text { Gavino AC, Elewski BE. (2013) [63] }\end{array}$ \\
\hline & vitamin $\mathrm{B}_{12}$ & Verdelli A, Antiga E, Bonciolini V, Bonciani D, Volpi W, Caproni M. (2014) [60] \\
\hline & vitamin $\mathrm{K}$ & Lembo S, Megna M, Balato A, Balato N. (2012) [64] \\
\hline & hydroxyurea & $\begin{array}{l}\text { García- Martínez FJ, García- Gavín J, Alvarez-Pérez A, Alonso-González J, Ginarte M, } \\
\text { Toribio J. (2012) [65] }\end{array}$ \\
\hline & antifolates & $\begin{array}{l}\text { Corbaux C, Marie J, Meraud JP, Lacroix S, Delhoume JY, Jouary T, Madoui S. (2015) } \\
{[66]}\end{array}$ \\
\hline & taxanes & $\begin{array}{l}\text { Pedersen JV, Jensen S, Krarup-Hansen A, Riis L. (2010) [71], Konishi Y, Sato H, Sato N, } \\
\text { Fujimoto T, Fukuda J, Tanaka T. (2010) [72], Torregrosa JL, Fernández M, Garcías J, } \\
\text { Pérez A. (2014) [73] }\end{array}$ \\
\hline & balicatib & $\begin{array}{l}\text { Rünger TM, Adami S, Benhamou CL, Czerwiński E, Farrerons J, Kendler DL, Mindeholm } \\
\text { L, Realdi G, Roux C, Smith V. (2012) [74] }\end{array}$ \\
\hline \multirow{5}{*}{$\begin{array}{l}\text { Coexistence of } \\
\text { scleroderma with } \\
\text { oncologic } \\
\text { diseases: }\end{array}$} & multiple myeloma & Gajendra S., Gupta R, Gupta R, Kumar L. (2013) [79] \\
\hline & malignant carcinoid syndrome & Becher G, Leman J. (2013) [79] \\
\hline & odontogenic carcinoma & McNamara PH, Toner M, Kearns G, Keohane C, Daly P, Doherty CP. (2013) [78] \\
\hline & squamous cell carcinoma & $\begin{array}{l}\text { Saleh DB, Williams AM, Smith IM.(2011) [80], Durčanská V, Jedličková H, Sláma O, } \\
\text { Velecký L, Březinová E, Vašků V. (2014) [81], Grewal I, Khan O, Davis W. (2014) [82] }\end{array}$ \\
\hline & $\begin{array}{l}\text { localized scleroderma induced by } \\
\text { radiotherapy prescribed for breast } \\
\text { cancer }\end{array}$ & $\begin{array}{l}\text { Akay BN, Sanli H, Heper AO. (2010) [94], de Giorgi V, Santi R, Grazzini M, Papi F, Gori } \\
\text { A, Rossari S, Massi D, Lotti T.(2010) [91], Laetsch B, Hofer T, Lombriser N, } \\
\text { Lautenschlager S. (2011) [85], Wernicke AG, Goltser Y, Trichter S, Sabbas A, Gaan J, } \\
\text { Swistel AJ, Magro CM. (2011) [86], Llenas J, Bringas A, Nocito J, Gómez Zanni S, } \\
\text { Campana R, Papa M. (2012) [87], Newland K, Marshman G. (2012) [88], Lim D, Johnston } \\
\text { S, Novakovic L, Fearfield L. (2014) [89], Reynolds TD, Knights SE. (2014) [84], } \\
\text { Vigneron C, Bauer N, Waisse W, Keller A, Pop M, Clavier JB, Salze P, Noël G. (2014) } \\
\text { [93], Spalek M, Jonska- Gmyrek J, Gałecki J. (2015) [92], Yanaba K, Umezawa Y, } \\
\text { Nakagawa H. . (2015) [90] }\end{array}$ \\
\hline
\end{tabular}

\section{The Endocrine Changes}

The endocrine changes are considered contributing to the development of autoimmune disease. It is well known that different types of scleroderma can follow pregnancy [9 - 11]. L. Benchat \& F.Z. Mernissi, (2013) suppose that pregnancy can be a predisposing factor of localized scleroderma because of microchimerism. According to the opinion of L. Benchat \& F.Z. Mernissi, (2013), chimeric cells are non-self cells transferred from fetus to mother during pregnancy [10].

Wong B \& colleagues, (2015) reported a case of linear localized scleroderma in a 21- year old woman in her early first trimester of pregnancy. The patient suffered from Graves' disease and was also cytomegalovirus positive. The case highlighted the combination of risk factors [11].

Hassan I \& colleagues, (2014) examined thyroid dysfunctions in morphoea. The levels of thyroid stimulating hormone were elevated with $41.2 \%$ patients [12].

Bonilla-Abadia F.\& colleagues,(2012) reported a case presenting an association of localized scleroderma, vitiligo, autoimmune thyroidism, pneumonitis, autoimmune thrombocytopenic purpura and central nervous system vasculitis. Localized scleroderma seemed to be a part of multiple autoimmune syndrome [13]. There are many reports of localized scleroderma associated with vitiligo in patients with thyroid disfunction [14 - 16]. Association of localized scleroderma with other autoimmune diseases emphasizes autoimmune etiology of localized scleroderma.

The typical association with other autoimmune diseases, as seen in generalized vitiligo, seems to be significantly less in segmental vitiligo [17].

However, there are some reports of localized scleroderma associated with vitiligo in patients without thyroid disfunction [18 - 20]. Apart from these surveys, a case of segmental vitiligo involving the left side of the trunk and left upper limb with segmental morphea involving the right side of trunk and right upper limb was present in an 18-year old 
girl. A history of type II diabetes mellitus in the father was elicited [21].

Localized scleroderma was diagnosed in diabetes mellitus patients, as well [22].

\section{Trauma}

Different physical injuries are known to be a triggering factor for scleroderma development. Arif T. \& colleagues, (2015) reported a case of linear localized scleroderma in a 26-year old woman with a lesion on the frontal and forehead regions. The patient mentioned that she had had a trauma at the same site six years back [23]. Trauma was the triggering factor as well in the development of linear scleroderma in a 32-year old woman. The skin lesion remained localized to the forehead during the subsequent 12 years and then the new lesions progressed down. The question of the possibility of quiescent period in the development of scleroderma was discussed [24]. The cross-sectional analysis of the localized scleroderma in adults and children cohort (MAC) was performed by Grabell D \& colleagues, (2014) [25]. 52 (16\%) among 329 patients in the MAC cohort had trauma-associated lesions at the onset of disease. Patients with lesions in an isotopic distribution had greater clinical severity as measured by a clinical outcome measure [25]. Another crosssectional survey of the MAC cohort emphasized the role of skin trauma [26]. The mechanical compression from clothes [27], particularly slim belt, is discussed [27]. The appearance of localized scleroderma lesions after fluoroscopy, laparotomy and rhinoplasty was outlined [28 - 30].

A case of a morphea profunda in a 50-year-old woman with a history of trauma sustained in an automobile accident was reported [31]. Vibration can influence the appearance of scleroderma, as well [32]. Ueda T \& colleagues, (2010) presented a case of linear scleroderma developed approximately 3 months after contusion and treatment by local injection of mepivacaine hydrochloride [33].

\section{Viral and Bacterial Infections}

A potential triggering role of CMV primary infection in the development of scleroderma is discussed [34]. ParryRomberg syndrome, frequently associated with localized scleroderma, is known to be provoked by viral infections [35]. Some cases of localized scleroderma following varicella were described earlier. Qu T \& Fang K., (2014) presented another possible connection of localized scleroderma with Varicella Zoster. A case of bullous morphea arising at the site of a healed herpes zoster was described [36]. HIV infection associated with scleroderma is also known, and the immunodeficient status may be predisposing for localized scleroderma development in these cases [37].

The question of the role of Borrelia infection still remains controversial [38 - 49]. Different diagnostic methods may be crucial for the estimation of the Borrelia significance. For example, the investigation performed in Mexico showed a lack of IgG antibody seropositivity to Borrelia burgdorferi in patients with Parry-Romberg syndrome and linear morphea en coup de sabre [48]. The results of PCR-based studies do not argue for a significant association of B. burgdorferi sensu lato with localized scleroderma [39]. On the other hand, Verberkt RM and colleagues, (2014) emphasized that focus floating microscopy proved to be more sensitive than polymerase chain reaction and observed to be nearly equally specific [49].

Not only infections, but also vaccination can induce scleroderma [50 - 53]. Morphoea profunda after hepatitis B vaccination was described [50]. In another case, morphoea profunda appeared 3 months after a third dose of diphtheriatetanus-pertussis vaccine [51]. Measles/mumps/rubella vaccine is also known as a factor, which may be provocative for the development of localized scleroderma [52]. Morphoea profunda after pneumococcal vaccination was also described [53].

\section{Chemical and Pharmaceutical Agents}

The incidences of localized scleroderma and systemic sclerosis have increased in patients with preceding exposure to particular substances. Scleroderma can be induced by some chemical agents, for example pesticides containing malathion and diniconazole [54]. Localized scleroderma is occasionally linked with exposure to chemical compounds such as silicone [55]. The disease was described as a sign of autoimmune syndrome induced by adjuvants [56].

Valproate is known to provoke the development of autoimmune diseases $[57,58]$. The exposure to valproate can cause sclerodermal skin changes [59].

Several classes of drugs seem to be capable of inducing or exacerbating localized scleroderma [60]. The treatment with TNF-alpha inhibitors can induce localized scleroderma development [61 - 63]. Scleroderma-like cutaneous changes may be caused by vitamin $B_{12}$ [60], vitamin $\mathrm{K}$ [64] and hydroxyurea [65]. On the other hand, patients with 
autoimmune diseases are diagnosed with increased frequencies of some cancers, which may depend on treatment.

Moreover the treatment of oncologic diseases can also provoke the development of localized scleroderma. The antifolates may cause scleroderma-like induration of the skin [66]. Bleomycin can also cause scleroderma-like changes and nowadays is used for mouse model of scleroderma [67 - 70]. The taxanes can also cause scleroderma-like lesions [71 - 73]. The usage of cathepsin $\mathrm{K}$ inhibitor balicatib has an adverse effect of skin hardening and morphoea-like changes, as well [74].

\section{Scleroderma and Oncologic Diseases}

The autoimmune diseases are associated with an increased risk of malignancy [75]. Dysregulation of the immune system underlies systemic sclerosis [76]. In localized scleroderma [77, 78] indicated to possible association with oncologic diseases.

Co-existence of scleroderma and multiple myeloma was described by Gajendra S. \& colleagues, (2013) [79]. Squamous cell carcinoma is known to develop in localized scleroderma patients [80 - 82]. Paraneoplastic scleroderma is described, as well [83, 84]. Jedlickova H \& colleagues, (2016) regard neoplasia as a distinct triggering impulse for scleroderma. The patients with paraneoplastic scleroderma were characterized by older age, sudden onset, diffuse thickening of the skin, and/or generalized morphea with a concurrent neoplastic disease. When the tumor treatment was successful, skin changes regressed. Further studies may confirm the true link between scleroderma and malignancy [83].

Several cases describe the development of localized scleroderma induced by radiotherapy prescribed for breast cancer [84 - 94]. De Giorgi V \& colleagues, (2010) described synchronous cutaneous angiosarcoma, melanoma and localized scleroderma, which developed within 14 years after radiotherapy of breast carcinoma [91]. Spalek M \& colleagues, (2015) presented the literature review that analyzed 66 cases reported in the literature since 1989 . The clinical appearance often includes pain and disfiguration of affected area, which may influence the patient's quality of life. There is no clear connection between the radiotherapy dose, the fractionation scheme, the use of a boost, age, the presence of other dermatological conditions or other connective tissue diseases and the occurrence of radiation-induced localized scleroderma [92]. Vigneron C and colleagues, (2014) believes that radiation-induced localized scleroderma is unrecognized and under-diagnosed [93]. The postirradiation linear morphea was described in a 74-year-old woman who was treated with radiotherapy for endometrial carcinoma. About 3,5 years after the first dose of radiotherapy, the patient developed linear localized sclerodermastarting from the radiation port and affecting distant, nonirradiated skin [94].

\section{DISCUSSION}

The genetic predisposition to localized scleroderma has been investigated in the recent years [4 - 8]. The triggering factors in genetically predisposed individuals might initially lead to an immunologically triggered release of proinflammatory cytokines, resulting in a profound dysregulation of the connective tissue metabolism and ultimately to induction of fibrosis [95]. Actually, there are no obligatory triggering factors, but each group of them can be crucial for a certain group of patients.

The physiological and pathological endocrine changes can precede the appearance of localized scleroderma [9 - 14]. The role of hormonal upregulation is being discussed as a possible trigger of autoimmunity [12 - 14]. As for pregnancy, it can be a predisposing factor of localized scleroderma because of microchimerism. The chimeric cells are non-self cells transferred from fetus to mother during pregnancy [10].

The trauma-associated lesions at the onset of disease were often mentioned [25 - 33]. The post-traumatic neurovascular changes are possible predisposing factors for the development of localized scleroderma.

The viral and bacterial infections are often discussed as provocative for the onset of autoimmune diseases. The role of Borrelia infection still remains unclear. The controversial opinions are presented in [38 - 49]. The different viral infections are also known to precede the appearance of localized scleroderma [34 - 37]. Anyhow, the viral and bacterial infections are not obligatory for the development of localized scleroderma, but seem to be the triggering factors. The different vaccinations are likely to be triggers, as well [50 - 53].

The localized scleroderma can be induced by some chemical agents (pesticides containing malathion and diniconazole, silicone, etc.) [54 - 56]. Different groups of pharmaceutical agents (valproate, TNF-alpha inhibitors, vitamin $\mathrm{B}_{12}$, vitamin $\mathrm{K}$, hydroxyurea, antifolates, taxanes etc.) can also provoke the onset of localized scleroderma 
[57 - 74]. We can suppose that the administration of these drugs might initially lead to an immunologically triggered release of pro-inflammatory cytokines and further development of localized scleroderma.

The patients with localized scleroderma are predisposed to oncologic diseases [77, 78], and vice versa, the development of localized scleroderma can be induced by radiotherapy prescribed for breast cancer [84 - 94]. Some cases of co-existence of localized scleroderma and other malignancies were also described [75 - 82]. The link between fibrosis, tumor progression, and cancer metastasis is being investigated. The impact of immune changes cannot be denied, either.

\section{CONCLUSION}

Analysing the publications on localized scleroderma, we can see the following predisposing and trigger factors:

- the genetic predisposition

- trauma

- some chemical substances (marathon, diniconazole, silicone)

- the pharmaceutical agents (valproate, TNF-alpha inhibitors, vitamin $\mathrm{B}_{12}$, vitamin $\mathrm{K}$, hydroxyurea, antifolates, taxanes)

- Borrelia burgdorferi and viral infections

- vaccinations

- radiotherapy for breast cancer

- the possibility of the development of paraneoplastic scleroderma

\section{CONFLICT OF INTEREST}

The author confirms that this article content has no conflict of interest.

\section{ACKNOWLEDGEMENTS}

Declared none.

\section{REFERENCES}

[1] Fett N. Scleroderma: nomenclature, etiology, pathogenesis, prognosis, and treatments: facts and controversies. Clin Dermatol 2013; 31(4): 432-7.

[http://dx.doi.org/10.1016/j.clindermatol.2013.01.010] [PMID: 23806160]

[2] Valančienė G, Jasaitienė D, Valiukevičienė S. Pathogenesis and treatment modalities of localized scleroderma. Medicina (Kaunas) 2010; 46(10): 649-56. [PMID: 21393982]

[3] Tolkachjov SN, Patel NG, Tollefson MM. Progressive hemifacial atrophy: a review. Orphanet J Rare Dis 2015; $10: 39$. [http://dx.doi.org/10.1186/s13023-015-0250-9] [PMID: 25881068]

[4] Pham CM, Browning JC. Morphea affecting a father and son. Pediatr Dermatol 2010; 27(5): 536-7. [http://dx.doi.org/10.1111/j.1525-1470.2010.01277.x] [PMID: 21182646]

[5] Karaca NE, Aksu G, Karaca E, et al. Progressive morphea of early childhood tracing Blaschkos lines on the face: involvement of X chromosome monosomy in pathogenesis and clinical prognosis. Int J Dermatol 2011; 50(11): 1406-10. [http://dx.doi.org/10.1111/j.1365-4632.2011.04900.x] [PMID: 22004499]

[6] Lis-Święty A, Mierzwińska K, Wodok-Wieczorek K, Widuchowska M, Brzezińska-Wcisło L. Co-existence of lichen sclerosus and localized scleroderma in female monozygotic twins. J Pediatr Adolesc Gynecol 2014; 27(6): e133-6. [http://dx.doi.org/10.1016/j.jpag.2013.11.010] [PMID: 24841519]

[7] Canady J, Karrer S, Fleck M, Bosserhoff AK. Fibrosing connective tissue disorders of the skin: molecular similarities and distinctions. J Dermatol Sci 2013; 70(3): 151-8.

[http://dx.doi.org/10.1016/j.jdermsci.2013.03.005] [PMID: 23631956]

[8] Jacobe H, Ahn C, Arnett FC, Reveille JD. Major histocompatibility complex class I and class II alleles may confer susceptibility to or protection against morphea: findings from the Morphea in Adults and Children cohort. Arthritis Rheumatol 2014; 66(11): $3170-7$. [http://dx.doi.org/10.1002/art.38814] [PMID: 25223600]

[9] Noda S, Asano Y, Ashida R, Tomita M, Kawashima T, Sato S. Localized scleroderma en coup de sabre exacerbated during pregnancy followed by postpartum development of rheumatoid arthritis. Eur J Dermatol 2011; 21(3): 441-2. 
[PMID: 21524983]

[10] Benchat L, Mernissi FZ. Morphea on the breast and pregnancy. Pan Afr Med J 2013; 16: 22. [http://dx.doi.org/10.11604/pamj.2013.16.22.3317] [PMID: 24570783]

[11] Wong B, Pilouras P, Mortimore R, Zonta M, Tucker S. Lower limb linear morphoea in a pregnant woman with known Graves' disease and cytomegalovirus immunoglobulin M positivity. Australas J Dermatol 2015; 56(4): 96-8.

[12] Hassan I, Arif T, Anwar P. Thyroid dysfunctions in morphoea: a preliminary report. Indian J Dermatol Venereol Leprol 2014; 80(6): 579. [http://dx.doi.org/10.4103/0378-6323.144230] [PMID: 25382535]

[13] Bonilla- Abadia F, Muñoz- Buitron E, Ochoa CD, Carrascal E, Cañas CA. A rare association of localized scleroderma type morphoea, vitiligo, autoimmune hypothyroidism, pneumonitis, autoimmune thrombocytopenic purpura and central nervous system vasculitis, Case report. BMC Res Notes 2012; 20(5): 689.

[14] Poojary SA. Vitiligo and associated autoimmune disorders: a retrospective hospital-based study in Mumbai, India. Allergol Immunopathol (Madr) 2011; 39(6): 356-61. [http://dx.doi.org/10.1016/j.aller.2010.12.007] [PMID: 21474231]

[15] Gill L, Zarbo A, Isedeh P, Jacobsen G, Lim HW, Hamzavi I. Comorbid autoimmune diseases in patients with vitiligo: A cross-sectional study J Am Acad Dermatol 2016; 74(2): 295-302. [http://dx.doi.org/10.1016/j.jaad.2015.08.063] [PMID: 26518171]

[16] Yorulmaz A, Kilic S, Artuz F, Kahraman E. Concomitant appearance of morphea and vitiligo in a patient with autoimmune thyroiditis. Postepy Dermatol Alergol 2016; 33(4): 314-6. [http://dx.doi.org/10.5114/ada.2016.61610] [PMID: 27605907]

[17] van Geel N, Mollet I, Brochez L, et al. New insights in segmental vitiligo: case report and review of theories. Br J Dermatol 2012; 166(2): 240-6. [http://dx.doi.org/10.1111/j.1365-2133.2011.10650.x] [PMID: 21936857]

[18] Bowen C, Kobayashi TT. What is your diagnosis? Segmental vitiligo and en coup de sabre. Cutis 2010; 85(5): 230-8. [PMID: 20540411]

[19] Martínez-García S, Fernández-Ballesteros MD, Segura-Palacios JM. Vitiligo and morphea: autoimmune cutaneous side effects of interferon treatment. Actas Dermosifiliogr 2012; 103(3): 250-1. Vitiligo and morphea: autoimmune cutaneous side effects of interferon treatment. [Article in Spanish]. [http://dx.doi.org/10.1016/j.adengl.2011.06.002] [PMID: 22056259]

[20] Janowska M, Podolec K, Lipko-Godlewska S, Wojas-Pelc A. Coexistence of Parry-Romberg syndrome with homolateral segmental vitiligo. Postepy Dermatol Alergol 2013; 30(6): 409-11. [http://dx.doi.org/10.5114/pdia.2013.39441] [PMID: 24494006]

[21] Yadav P, Garg T, Chander R, Nangia A. Segmental vitiligo with segmental morphea: An autoimmune link? Indian Dermatol Online J 2014; 5(Suppl. 1): S23-5. [http://dx.doi.org/10.4103/2229-5178.144517] [PMID: 25506558]

[22] Firoz EF, Kamino H, Lehman TJ, Orlow SJ. Morphea, diabetes mellitus type I, and celiac disease: case report and review of the literature. Pediatr Dermatol 2010; 27(1): 48-52. [http://dx.doi.org/10.1111/j.1525-1470.2009.00907.x] [PMID: 20199410]

[23] Arif T, Majid I, Ishtiyaq Haji ML. Late onset "en coup de sabre” following trauma: rare presentation of a rare disease. Our Dermatol Online 2015; 6(1): 49-51.

[http://dx.doi.org/10.7241/ourd.20151.12]

[24] Arif T, Majid I. Can lesions of “en coup de sabre" progress after being quiescent for a decade? Iran J Dermatol 2015; 18: 77-9.

[25] Grabell D, Hsieh C, Andrew R, et al. The role of skin trauma in the distribution of morphea lesions: a cross-sectional survey of the Morphea in Adults and Children cohort IV. J Am Acad Dermatol 2014; 71(3): 493-8. [http://dx.doi.org/10.1016/j.jaad.2014.04.009] [PMID: 24880663]

[26] Wolf R, Wolf D, Ruocco V, Ruocco E. The role of skin trauma (isotopic and isomorphic) in the distribution of morphea. J Am Acad Dermatol 2015; 72(3): 560-1.

[http://dx.doi.org/10.1016/j.jaad.2014.10.046] [PMID: 25687315]

[27] Arif T, Hassan I, Anwar P, Amin SS. Slim belt induced morphea. Price paid for a slimmer look. Our Dermatol Online 2015; 6(3): 347-9. [http://dx.doi.org/10.7241/ourd.20153.93]

[28] Careta MF, Romiti R. Localized scleroderma: clinical spectrum and therapeutic update. An Bras Dermatol 2015; 90(1): 62-73. [http://dx.doi.org/10.1590/abd1806-4841.20152890] [PMID: 25672301]

[29] Browning JC. Pediatric morphea. Dermatol Clin 2013; 31(2): 229-37. [http://dx.doi.org/10.1016/j.det.2012.12.002] [PMID: 23557652]

[30] Fett N, Werth VP. Update on morphea: part I. Epidemiology, clinical presentation, and pathogenesis. J Am Acad Dermatol 2011; 64(2): 217-28

[http://dx.doi.org/10.1016/j.jaad.2010.05.045] [PMID: 21238823] 
[31] Touloei K, Wiener A, Glick BP. Solitary morphea profunda following trauma sustained in an automobile accident. Cutis 2015; 95(1): 32-6. [PMID: 25671442]

[32] Gerceker Turk B, Urkmez A, Kilinc Karaarslan I, Ertam I, Kandiloglu G, Dereli T. Unilateral generalized morphoea: could vibration be a stimulating factor? Clin Exp Dermatol 2010; 35(4): e165-6. [http://dx.doi.org/10.1111/j.1365-2230.2009.03760.x] [PMID: 20015285]

[33] Ueda T, Niiyama S, Amoh Y, Katsuoka K. Linear scleroderma after contusion and injection of mepivacaine hydrochloride. Dermatol Online J 2010; 16(5): 11 . [PMID: 20492828]

[34] Goulabchand R, Khellaf L, Forestier A, et al. Acute and regressive scleroderma concomitant to an acute CMV primary infection. J Clin Virol 2014; 61(4): 604-7.

[http://dx.doi.org/10.1016/j.jcv.2014.10.003] [PMID: 25453335]

[35] Patel H, Thakkar C, Patel K. Parry-romberg syndrome: a rare entity. J Maxillofac Oral Surg 2010; 9(3): $247-50$. [http://dx.doi.org/10.1007/s12663-010-0103-y] [PMID: 22190798]

[36] Qu T, Fang K. Bullous morphea arising at the site of a healed herpes zoster. J Dermatol 2014; 41(6): 553-4. [http://dx.doi.org/10.1111/1346-8138.12427] [PMID: 24750285]

[37] Mosquera JA, Ojea R, Navarro C. HIV infection associated with scleroderma: report of two new cases. J Clin Pathol 2010; 63(9): 852-3. [http://dx.doi.org/10.1136/jcp.2010.080044] [PMID: 20819885]

[38] Espinoza-León F, Arocha F, Hassanhi M, Arévalo J. Using the polymerase chain reaction to Borrelia burgdorferi infection in localized scleroderma injure (morphea), in Venezuelan patients. Invest Clin 2010; 51(3): 381-90. [PMID: 21305774]

[39] Santos M, Ribeiro-Rodrigues R, Talhari C, Ferreira LC, Zelger B, Talhari S. Presence of Borrelia burgdorferi Sensu Lato in patients with morphea from the Amazonic region in Brazil. Int J Dermatol 2011; 50(11): 1373-8.

[http://dx.doi.org/10.1111/j.1365-4632.2011.05081.x] [PMID: 22004491]

[40] Moniuszko A, Gińdzieńska-Sieśkiewicz E, Pancewicz SA, Czupryna P, Zajkowska J, Sierakowski S. Evaluation of skin thickness lesions in patients with Lyme disease measured by modified Rodnan total skin score. Rheumatol Int 2012; 32(10): 3189-91. [http://dx.doi.org/10.1007/s00296-011-2157-7] [PMID: 21960047]

[41] Miglino B, Viana M, Zavattaro E, Bonin S, Valente G, Colombo E. Localized scleroderma unius lateri and Borrelia burgdoferi infection. Indian J Dermatol Venereol Leprol 2012; 78(3): 383-5. [http://dx.doi.org/10.4103/0378-6323.95460] [PMID: 22565449]

[42] Miller K, Lehrhoff S, Fischer M, Meehan S, Latkowski JA. Linear morphea of the forehead (en coup de sabre). Dermatol Online J 2012; 18(12): 22 .

[PMID: 23286812]

[43] Inci R, Inci MF, Ozkan F, Oztürk P. Frontal linear scleroderma en coup de sabre associated with epileptic seizure. BMJ Case Rep 2012. 2012. pii: bcr2012007837. [http://dx.doi.org/10.1136/bcr-2012-007837]

[44] di Meo N, Stinco G, Nan K, Pinzani C, Trevisan G. Parry-Romberg syndrome: a case with a possible association with Lyme disease. Acta Dermatovenerol Alp Panonica Adriat 2015; 24(4): 77-9. [PMID: 26697732]

[45] Aberer E, Wutte N. Atrophosclerodermic manifestations of Lyme Borreliosis. Open Dermatol J 2016; 10(10)((suppl.1: M4)): 24-43. [http://dx.doi.org/10.2174/1874372201610010027]

[46] Trevisan G, Trevisini S, di Meo N. Lyme Borreliosis. Open Dermatol J 2016; 10(10)((suppl.1: M4)): 1-5. [http://dx.doi.org/10.2174/1874372201610010001]

[47] Zollinger T, Mertz KD, Schmid M, Schmitt A, Pfaltz M, Kempf W. Borrelia in granuloma annulare, morphea and lichen sclerosus: a PCRbased study and review of the literature. J Cutan Pathol 2010; 37(5): 571-7. [http://dx.doi.org/10.1111/j.1600-0560.2009.01493.x] [PMID: 20015188]

[48] Gutiérrez-Gómez C, Godínez-Hana AL, García-Hernández M, et al. Lack of IgG antibody seropositivity to Borrelia burgdorferi in patients with Parry-Romberg syndrome and linear morphea en coup de sabre in Mexico. Int J Dermatol 2014; 53(8): $947-51$. [http://dx.doi.org/10.1111/ijd.12105] [PMID: 24527729]

[49] Verberkt RM, Janssen M, Wesseling J. A boy with a tight skin: Borrelia-associated early-onset morphea. Clin Exp Rheumatol 2014; 32(1): $121-2$. [PMID: 24093617]

[50] Benmously Mlika R, Kenani N, Badri T, et al. Morphea profunda in a young infant after hepatitis B vaccination. J Am Acad Dermatol 2010; 63(6): 1111-2. [http://dx.doi.org/10.1016/j.jaad.2009.02.047] [PMID: 21093674]

[51] Khaled A, Kharfi M, Zaouek A, et al. Postvaccination morphea profunda in a child. Pediatr Dermatol 2012; $29(4): 525-7$. [http://dx.doi.org/10.1111/j.1525-1470.2011.01548.x] [PMID: 21854420] 
[52] Weibel L. [Localized scleroderma (morphea) in childhood]. Hautarzt 2012; 63(2): 89-96. [http://dx.doi.org/10.1007/s00105-011-2199-5] [PMID: 22290277]

[53] Viladomiu EdelA, Valls AT, Zabaleta BA, Moreno AJ, Pérez NO. Deep morphea in a child after pneumococcal vaccination. Indian J Dermatol Venereol Leprol 2014; 80(3): 259-60.

[http://dx.doi.org/10.4103/0378-6323.132259] [PMID: 24823409]

[54] Sozeri B, Gulez N, Aksu G, Kutukculer N, Akalın T, Kandiloglu G. Pesticide-induced scleroderma and early intensive immunosuppressive treatment. Arch Environ Occup Health 2012; 67(1): 43-7. [http://dx.doi.org/10.1080/19338244.2011.564231] [PMID: 22315935]

[55] Kivity S, Katz M, Langevitz P, Eshed I, Olchovski D, Barzilai A. Autoimmune syndrome induced by adjuvants (ASIA) in the Middle East: morphea following silicone implantation. Lupus 2012; 21(2): 136-9. [http://dx.doi.org/10.1177/0961203311429551] [PMID: 22235043]

[56] Frances L, Leiva-Salinas M, Angelica MB, Marin I, Silvestre JF. Morphea as a sign of autoimmune syndrome induced by adjuvants (ASIA). Eur J Dermatol 2014; 24(3): 377-8. [PMID: 24721905]

[57] Nanau RM, Neuman MG. Adverse drug reactions induced by valproic acid. Clin Biochem 2013; 46(15): $1323-38$. [http://dx.doi.org/10.1016/j.clinbiochem.2013.06.012] [PMID: 23792104]

[58] Guzmán-Sánchez D, Asz-Sigall D. Alopecias due to drugs and other skin and systemic disorders. Curr Probl Dermatol 2015; 47: 97-106. [http://dx.doi.org/10.1159/000369409] [PMID: 26370648]

[59] Aslan A, Kotoroglu G, Sözeri B, Kurugöl Z. Systemic scleroderma in childhood:a case report. Archiv Rheumatol 2014; $29(3)$ : 219-33. [http://dx.doi.org/10.5606/ArchRheumatol.2014.3684]

[60] Verdelli A, Antiga E, Bonciolini V, Bonciani D, Volpi W, Caproni M. Drug induction in connective tissue diseases. G Ital Dermatol Venereol 2014; 149(5): 573-80. [PMID: 24975950]

[61] Mattozzi C, Richetta AG, Cantisani C, et al. Morphea, an unusual side effect of anti-TNF-alpha treatment. Eur J Dermatol 2010; 20(3): 400-1. [PMID: 20299314]

[62] Ramírez J, Hernández MV, Galve J, Cañete JD, Sanmartí R. Morphea associated with the use of adalimumab: a case report and review of the literature. Mod Rheumatol 2012; 22(4): 602-4. [http://dx.doi.org/10.3109/s10165-011-0550-4] [PMID: 22095405]

[63] Stewart FA, Gavino AC, Elewski BE. New side effect of TNF-alpha inhibitors: morphea. Skinmed 2013; 11(1): 59-60. [PMID: 23540081]

[64] Lembo S, Megna M, Balato A, Balato N. Cowboys belt with revolver scleroderma caused by vitamin K1 injections. G Ital Dermatol Venereol 2012; 147(2): 203-5. [PMID: 22481583]

[65] García-Martínez FJ, García-Gavín J, Alvarez-Pérez A, Alonso-González J, Ginarte M, Toribio J. Scleroderma-like syndrome due to hydroxyurea. Clin Exp Dermatol 2012; 37(7): 755-8. [http://dx.doi.org/10.1111/j.1365-2230.2011.04326.x] [PMID: 22439735]

[66] Corbaux C, Marie J, Meraud JP, et al. Pemetrexed-induced scleroderma-like changes in the lower legs. Ann Dermatol Venereol 2015; 142(2): 115-20. [http://dx.doi.org/10.1016/j.annder.2014.11.011] [PMID: 25554663]

[67] Castello-Cros R, Whitaker-Menezes D, Molchansky A, et al. Scleroderma-like properties of skin from caveolin-1-deficient mice: implications for new treatment strategies in patients with fibrosis and systemic sclerosis. Cell Cycle 2011; 10(13): 2140-50. [http://dx.doi.org/10.4161/cc.10.13.16227] [PMID: 21670602]

[68] Kitaba S, Murota H, Terao M, et al. Blockade of interleukin-6 receptor alleviates disease in mouse model of scleroderma. Am J Pathol 2012; 180(1): 165-76.

[http://dx.doi.org/10.1016/j.ajpath.2011.09.013] [PMID: 22062222]

[69] Ozgen M, Koca SS, Dagli AF, Gundogdu B, Ustundag B, Isik A. Mycophenolate mofetil and daclizumab targeting T lymphocytes in bleomycin-induced experimental scleroderma. Clin Exp Dermatol 2012; 37(1): 48-54. [http://dx.doi.org/10.1111/j.1365-2230.2011.04201.x] [PMID: 22182434]

[70] Koca SS, Ozgen M, Sarikaya M, Dagli F, Ustundag B, Isik A. Ghrelin prevents the development of dermal fibrosis in bleomycin-induced scleroderma. Clin Exp Dermatol 2014; 39(2): 176-81. [http://dx.doi.org/10.1111/ced.12195] [PMID: 24033834]

[71] Pedersen JV, Jensen S, Krarup-Hansen A, Riis L. Scleroderma induced by paclitaxel. Acta Oncol 2010; 49(6): 866-8. [http://dx.doi.org/10.3109/02841861003702510] [PMID: 20446892]

[72] Konishi Y, Sato H, Sato N, Fujimoto T, Fukuda J, Tanaka T. Scleroderma-like cutaneous lesions induced by paclitaxel and carboplatin for ovarian carcinoma, not a single course of carboplatin, but re-induced and worsened by previously administrated paclitaxel. J Obstet Gynaecol Res 2010; 36(3): 693-6. [http://dx.doi.org/10.1111/j.1447-0756.2010.01171.x] [PMID: 20598060] 
[73] Torregrosa JL, Fernández M, Garcías J, Pérez A. Morphea type plaques induced by paclitaxel. Med Clin (Barc) 2014; 142(9): 424-5. [http://dx.doi.org/10.1016/j.medcli.2013.06.023] [PMID: 24018254]

[74] Rünger TM, Adami S, Benhamou CL, et al. Morphea-like skin reactions in patients treated with the cathepsin K inhibitor balicatib. J Am Acad Dermatol 2012; 66(3): e89-96. [http://dx.doi.org/10.1016/j.jaad.2010.11.033] [PMID: 21571394]

[75] Hemminki K, Liu X, Ji J, Försti A, Sundquist J, Sundquist K. Effect of autoimmune diseases on risk and survival in female cancers. Gynecol Oncol 2012; 127(1): 180-5. [http://dx.doi.org/10.1016/j.ygyno.2012.07.100] [PMID: 22819787]

[76] Katzen JB, Raparia K, Agrawal R, et al. Early stage lung cancer detection in systemic sclerosis does not portend survival benefit: a cross sectional study. PloS One 2015; 10(2): e 0117829. . [http://dx.doi.org/10.1371/journal.pone.0117829]

[77] Becher G, Leman J. Cutaneous scleroderma and malignant carcinoid syndrome. Clin Exp Dermatol 2013; 38(3): 310-1. [http://dx.doi.org/10.1111/ced.12046] [PMID: 23517363]

[78] McNamara PH, Toner M, Kearns G, Keohane C, Daly P, Doherty CP. Focal seizures secondary to cortical dysplasia associated with isolated oral morphea and odontogenic carcinoma. Seizure 2013; 22(2): 159-61. [http://dx.doi.org/10.1016/j.seizure.2012.11.009] [PMID: 23280274]

[79] Gajendra S, Gupta R, Gupta R, Kumar L. Coexistence of scleroderma with multiple myeloma: a rare association. BMJ Case Rep 2013; 2013: bcr2013200639. [http://dx.doi.org/10.1136/bcr-2013-200639] [PMID: 24022902]

[80] Saleh DB, Williams AM, Smith IM. Cutaneous squamous cell carcinoma arising within generalised morphea. J Plast Reconstr Aesthet Surg 2011; 64(6): e149-52.

[http://dx.doi.org/10.1016/j.bjps.2011.01.019] [PMID: 21420372]

[81] Durčanská V, Jedličková H, Sláma O, Velecký L, Březinová E, Vašků V. Squamous cell carcinoma in localized scleroderma. Klin Onkol 2014; 27(6): 434-7.

[http://dx.doi.org/10.14735/amko2014434] [PMID: 25493583]

[82] Grewal I, Khan O, Davis W. Squamous cell carcinoma and eosinophilia in a long-term course of pansclerotic morphea BMJ Case Rep 2014; 13(6): pii: bcr2014205737..

[83] Jedlickova H, Durčanská V, Vašků V. Paraneoplastic scleroderma: are there any clues? Acta Dermatovenerol Croat 2016; 24(1): 78-80. [PMID: 27149136]

[84] Reynolds TD, Knights SE. Recurrent metastatic breast cancer presenting with paraneoplastic scleroderma. BMJ Case Rep 2014. pii: bcr2014203575

[http://dx.doi.org/10.1136/bcr-2014-203575]

[85] Laetsch B, Hofer T, Lombriser N, Lautenschlager S. Irradiation-induced morphea: X-rays as triggers of autoimmunity. Dermatology (Basel) $2011 ; 223(1): 9-12$. [http://dx.doi.org/10.1159/000330324] [PMID: 21865672]

[86] Wernicke AG, Goltser Y, Trichter S, et al. Morphea as a consequence of accelerated partial breast irradiation. Clin Breast Cancer 2011; 11(1): $67-70$.

[http://dx.doi.org/10.3816/CBC.2011.n.012] [PMID: 21421525]

[87] Llenas J, Bringas A, Nocito J, Gómez Zanni S, Campana R, Papa M. Post-irradiation morphea in brest cancer: a case report. Rev Fac Cien Med Univ Nac Cordoba 2012; 69(3): 162-4. [PMID: 23286579]

[88] Newland K, Marshman G. Success treatment of post-irradiation morphoea with acitretin and narrowband UVB. Australas J Dermatol 2012; 53(2): 136-8. [http://dx.doi.org/10.1111/j.1440-0960.2011.00864.x] [PMID: 22571564]

[89] Lim D, Johnston S, Novakovic L, Fearfield L. Radiation-induced morphoea treated with UVA-1 phototherapy. Clin Exp Dermatol 2014; 39(5): 612-5.

[http://dx.doi.org/10.1111/ced.12345] [PMID: 24890985]

[90] Yanaba K, Umezawa Y, Nakagawa H. A case of radiation-induced generalized morphea with prominent mucin deposition and tenderness. Am J Case Rep 2015; 16: 279-82. [http://dx.doi.org/10.12659/AJCR.893481] [PMID: 25958415]

[91] de Giorgi V, Santi R, Grazzini M, et al. Synchronous angiosarcoma, melanoma and morphea of the breast skin 14 years after radiotherapy for mammary carcinoma. Acta Derm Venereol 2010; 90(3): 283-6. [http://dx.doi.org/10.2340/00015555-0841] [PMID: 20526547]

[92] Spalek M, Jonska-Gmyrek J, Gałecki J. Radiation-induced morphea - a literature review. J Eur Acad Dermatol Venereol 2015; 29(2): $197-202$.

[http://dx.doi.org/10.1111/jdv.12704] [PMID: 25174551] 
[93] Vigneron C, Bauer N, Waisse W, et al. Radio-induced breast morphoea: an unrecognized complication. Cancer Radiother 2014 ; $18(1)$ : 64-7. [http://dx.doi.org/10.1016/j.canrad.2013.09.006] [PMID: 24309003]

[94] Akay BN, Sanli H, Heper AO. Postirradiation linear morphoea. Clin Exp Dermatol 2010; 35(4): e106-8. [http://dx.doi.org/10.1111/j.1365-2230.2009.03717.x] [PMID: 19874351]

[95] Kreuter A. Localized scleroderma. Dermatol Ther (Heidelb) 2012; 25(2): 135-47. [http://dx.doi.org/10.1111/j.1529-8019.2012.01479.x] [PMID: 22741933]

(C) Irina Khamaganova; Licensee Bentham Open

This is an open access article licensed under the terms of the Creative Commons Attribution-Non-Commercial 4.0 International Public License (CC BY-NC 4.0) (https://creativecommons.org/licenses/by-nc/4.0/legalcode), which permits unrestricted, non-commercial use, distribution and reproduction in any medium, provided the work is properly cited. 